\title{
Preventive management of undesired changes in alongshore sediment transport in the planning of a waterfront infrastructure
}

\author{
A. Käärd ${ }^{1}$, A. Valdmann ${ }^{1}$, M. Eelsalu ${ }^{2}$, K. Pindsoo ${ }^{2}$, R. Männikus ${ }^{2}$ \\ \& T. Soomere ${ }^{2}$ \\ ${ }^{1}$ Tallinn Municipal Engineering Services, Tallinn, Estonia \\ ${ }^{2}$ Institute of Cybernetics at Tallinn University of Technology, Estonia
}

\begin{abstract}
We show that undesired remote impacts of changes in the location of the waterfront may occur in fairly mild wave conditions. As an example, we analyse the consequences of a moderate reclamation action in the bayhead of Tallinn Bay, the Baltic Sea. The planned changes are fairly small: the waterfront will be shifted by a few tens of metres owing to the construction of a new major traffic junction. The potential impacts are established using generic concepts of the nature of coastal processes and a detailed reconstruction of the local wave climate. The main properties of closure depths and magnitude and direction of wave-driven alongshore transport in the entire bay are established using a triplenested high-resolution version of the wave model WAM that is forced for 32 years by high-quality marine winds. It is demonstrated that the planned reclamation area currently serves as a convergence point of alongshore sediment transport. Even though the closure depth is only about $2 \mathrm{~m}$, the presence of fine sand gives rise to a relatively wide equilibrium beach profile. The seaward end of this profile is currently close to the entrance to a major harbour about $0.5 \mathrm{~km}$ from the activity area. The pattern of sediment motions is such that even a minor shift in the coastline may lead to considerable increase in the transport of sand into the harbour entrance. We evaluate the time scale for this process based on laser scanning data about sand accumulation rates and the concept of equilibrium beach profile, and discuss the ways of preventive mitigation of the consequences of reclamation.
\end{abstract}

Keywords: coastal processes, sediment transport, waterfront, equilibrium beach profile, laser scanning, Baltic Sea, Tallinn Bay. 


\section{Introduction}

Expanding the level of land reclamation and coastal protection [1] and armouring [2] is one of the few feasible ways for the development of contemporary urban waterfronts [3]. While the waterfront redevelopment is an imperative in many occasions [4], the relocation or armouring of the waterfront requires careful planning in order to preventively eliminate or mitigate the consequences to the adjacent beach dynamics [5]. In particular, placing various coastal structures along sections of the erosional coastline often requires subsequent expensive defence measures even in relatively low-energy or sheltered coastal segments [6].

The construction of the waterfront infrastructure in locations with intense sediment transport has often substantial remote impact on the overall course of coastal processes. Such impacts are well known on high-energy open sea coasts but are often considered as minor in relatively sheltered locations.

We focus on a mirror problem of land reclamation and coastline armouring in an area of excess sand. The related general issues are possible changes in the marine and coastal ecosystem [7]. The situation is, however, highly nontrivial in areas with complicated geometry that host small-scale patterns of sediment transport. Even relatively small changes in the location of the shoreline may change the overall structure of sediment transport in such areas. We demonstrate that even seemingly insignificant changes in the location of the waterline may lead to considerable alterations in the pattern of nearshore processes and to intense silting of an adjacent harbour entrance.

The test area is a segment of the urban waterfront in the southern end of Tallinn Bay (Fig. 1). A short description of the planned changes to the shoreline and major hydrodynamic drivers of coastal processes in the interior of the bay is given in Section 2. Section 3 provides a brief insight into the set-up of the sediment transport model and qualitative results of simulations of wave-driven alongshore sediment motions. The routine of laser scanning techniques and the established accumulation rate in the study area are described in Section 4. The outcome of the qualitative analysis of the potential consequences of the planned reclamation is presented in Section 5 .

\section{Evaluation of wave properties and closure depths}

Tallinn Bay is located at the southern coast of the Gulf of Finland in the northeastern Baltic Sea (Fig. 1). It is one of the most famous venues of studies into the impact of anthropogenic waves produced by ships sailing at relatively high speeds in comparatively shallow water [8]. This small semi-enclosed water body has a size of about $10 \mathrm{~km} \times 20 \mathrm{~km}$ and is located in the almost tideless area; thus the evolution of its coasts is mostly governed by wind waves.

The planned construction site is located in the southernmost part of the bay in the vicinity of a monument to Russalka (a ship that sank in 1893 with the entire crew of 178 seamen). For brevity we shall call the site the "Russalka area". The aim is to construct a new key traffic junction on a major thoroughfare that 
bypasses the historical centre of Tallinn from the north and connects the harbours near the city centre with the main highways. The foreseen changes to the shoreline are fairly small. The entire construction only affects a section with a total length of $680 \mathrm{~m}$, whereas a shift of the coastline location is foreseen for a $520 \mathrm{~m}$ long segment. The maximum shift of the waterfront towards the offshore will be about $55 \mathrm{~m}$. The total amount of material used for filling the construction site is about $43,000 \mathrm{~m}^{3}$.

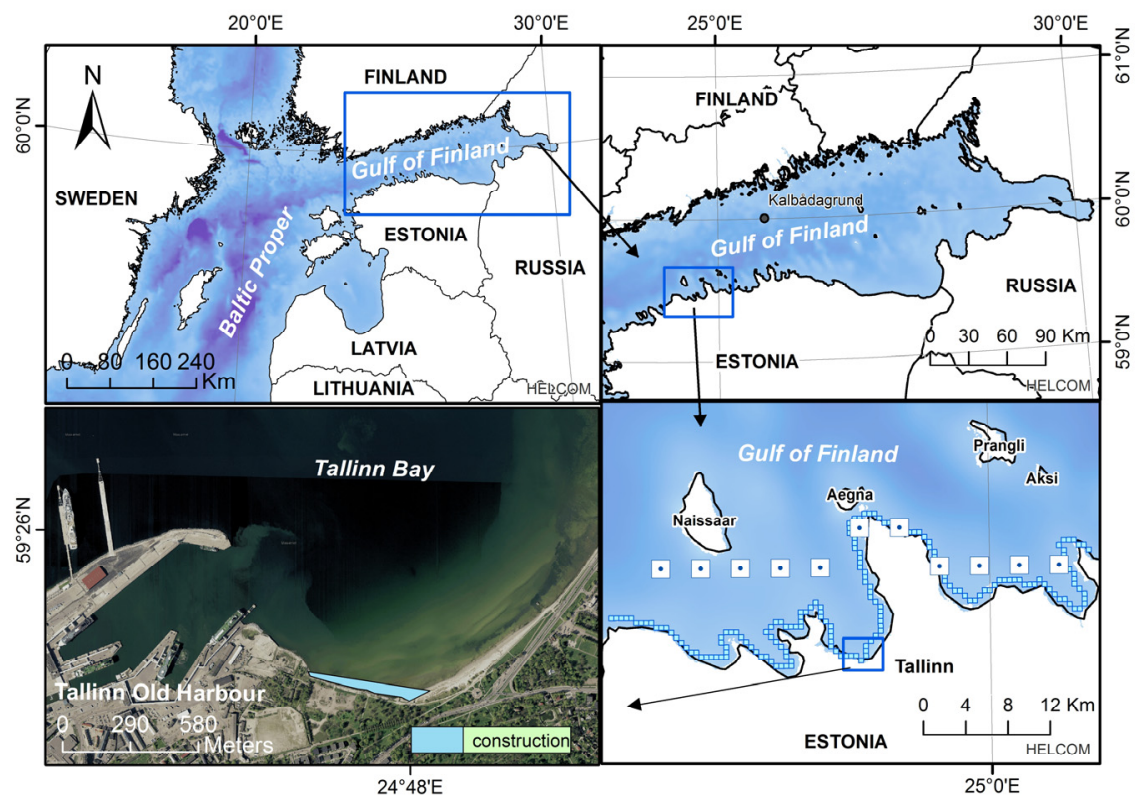

Figure 1: Location scheme of the study area in Tallinn Bay and computational areas of the triple-nested wave model. Small cyan squares along the coast in the lower right panel indicate grid points used in the analysis.

As Tallinn Bay is largely sheltered from predominant storm directions, it hosts a relatively mild wind wave climate. The significant wave height exceeds $0.5 \mathrm{~m}$ with a probability of only $10 \%$ in its interior. The wave climate, however, is extremely intermittent: $100-y r$ maximum wave heights exceed $4 \mathrm{~m}$ [9]. The fetch length for the largest waves that propagate into its interior is relatively short, less than $100 \mathrm{~km}$. Consequently, the peak periods of wind waves are usually well below $3 \mathrm{~s}$, reach $4-6 \mathrm{~s}$ in strong storms and only infrequently exceed 7-8 s [9].

The time series of parameters of wave properties (significant wave height, peak period and mean wave direction) in the nearshore of the study area (Fig. 2) were reconstructed using a triple-nested version of the wave model WAM. The resolution of the innermost grid was $470 \mathrm{~m}$. Although this model has been originally designed for relatively deep water, it properly replicates the Baltic Sea wave fields [10]. To adequately represent the wave growth in low wind and short 
fetch conditions (that are common at the study site), we used an increased frequency range of waves up to $2.08 \mathrm{~Hz}$. The presence of sea ice is ignored. Therefore, the hindcast parameters of closure depth or alongshore sediment transport may be somewhat overestimated. For details of the model set-up and its validation the reader is referred to [9].

Atmospheric models often fail to adequately replicate wind directions in the Gulf of Finland [11]. To ensure acceptable quality of wave hindcast and especially the adequacy of wave propagation directions (that largely govern alongshore transport), simulations were forced by high-quality one-point opensea wind data for 32 years (1981-2012). The measurement site, Kalbådagrund in the central part of Gulf of Finland (Fig. 1, 59 $59^{\prime} \mathrm{N}, 25^{\circ} 36^{\prime} \mathrm{E}$ ), is the only location of routine wind recordings in the entire area that is not affected by the presence of shores: the measurement devices are mounted on a caisson lighthouse located on the top of a shoal far offshore.

For this study we employed wave properties evaluated at the centres of nearshore grid cells of the innermost grid of the wave model. These cells (Figs 1 and 2) were selected close to the coast but still in a reasonable water depth $(\geq 4 \mathrm{~m})$ so that the modelled waves were not yet breaking. As alongshore sediment transport is commonly evaluated using wave properties at the seaward border of the surf zone, it was necessary to evaluate the properties of simulated waves at the breaking line. As is commonly in the Baltic Sea conditions [12], waves often approach the nearshore under relatively large angles with respect to the bottom isolines and the orientation of the corresponding shoreline segments.

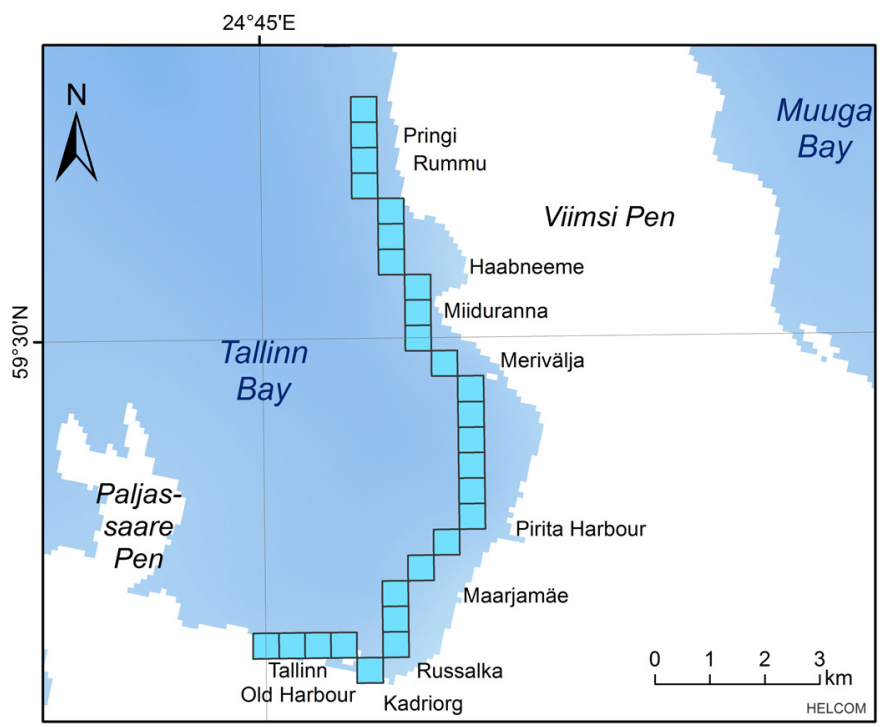

Figure 2: Location scheme of the wave model grid points and associated coastal sections in Tallinn Bay. 
Thus, it is necessary to take account of both refraction and shoaling in the calculation of the properties of waves at the breaking line.

We employed the approach developed in [13]. The numerically evaluated wave field is assumed to be monochromatic with the wave height $H_{0}$ equal to the modelled significant wave height in a selected cell, the period equal to the peak period and the approach direction equal to the evaluated mean direction. If the nearshore is locally homogeneous along the direction of the shoreline and the waves start to break when their height is $80 \%$ of the water depth (equivalently, the breaking index $\gamma_{b}=H_{b} / d_{b}=0.8 ; d_{b}$ is the local water depth), the wave height $H_{b}$ at the breaking line is given by the smallest real solution of the following equation:

$$
\frac{H_{b}^{5} g}{H_{0}^{4} \gamma_{b}}\left(1-\frac{g H_{b}}{\gamma_{b}} \frac{\sin ^{2} \theta_{0}}{c_{f 0}^{2}}\right)=c_{g 0}^{2}\left(1-\sin ^{2} \theta_{0}\right),
$$

Here $g$ is the gravity acceleration, $c_{g}$ is the group speed, $c_{f}$ is the phase speed, $\theta$ is the attack angle of the approaching waves and the subscripts " 0 " and " $b$ " indicate the relevant value in the particular grid cell and at the breaker line, respectively. As breaking waves are long waves, their group and phase speeds are equal: $c_{g b}=c_{f b}=\sqrt{g d_{b}}=\sqrt{g H_{b} / \gamma_{b}}$ at the breaker line.

Most of wave-driven alongshore sediment transport occurs in the surf zone, that is, landwards of the closure depth $d^{*}$. This quantity is commonly defined as the maximum depth at which the breaking waves effectively adjust the whole (equilibrium) profile [14], equivalently, as the depth where repeated survey profiles pinch out to a common line. Seawards from the closure depth, waves may occasionally move bottom sediments but they are not able to maintain a specific profile. For accreting beaches, the width of the equilibrium beach profile defines the distance from the coast at which accretion occurs systematically. This depth ranges between 1.96-2.59 $\mathrm{m}$ and 2.33-3.08 $\mathrm{m}$ (depending on the particular approximation) along the coastal segment where the shift of the waterline is planned [15]. As sediment is often in motion also at a certain distance offshore of the closure depth and very strong storms have occurred during the last decades [9], we use the smaller values from the listed range as a basis for a conservative estimate of the area of intense accretion in the nearshore.

\section{Alongshore sediment transport in the study area}

We evaluate the intensity of wave-driven alongshore sediment transport in the study area using the potential immersed weight transport rate (called simply the "transport rate" below) $I_{t}=\left(\rho_{s}-\rho\right) g(1-p) Q_{t}$ [16]. Here $Q_{t}$ is the potential alongshore transport rate and we use $\rho_{s}=2650 \mathrm{~kg} / \mathrm{m}^{3}$ and $\rho=1015 \mathrm{~kg} / \mathrm{m}^{3}$ for the densities of sand grains and sea water, respectively, and assume that the porosity coefficient is $p=0.4$. The commonly used so-called Coastal 
Engineering Research Center (CERC) approach assumes that $I_{t}=K P_{t}$, where $P_{t}=E c_{g b} \sin \theta_{b} \cos \theta_{b}$ is the rate of beaching of the wave energy flux $E c_{g}$ and $E$ is the wave energy (both evaluated at the breaker line). We employ the expression $K=0.05+2.6 \sin ^{2} 2 \theta_{b}+0.007 u_{m b} / w_{f}$ for the coefficient $K$ [16]. Here $u_{m b}=\left(h_{b} / 2\right) \sqrt{g / d_{b}}=\sqrt{g \gamma_{b} h_{b}} / 2$ is the maximum orbital velocity according to the linear wave theory and $w_{f}=1.6 \sqrt{g d_{50}\left(\rho_{s}-\rho\right) / \rho}$ is the fall velocity. An appreciable approximation for the typical grain size of sand in the study area is $d_{50}=0.17 \mathrm{~mm}[17]$.

The resulting 3-hourly transport rates are used to evaluate the annual means of the bulk and net (positive for counter-clockwise drift) transport for each about $500 \mathrm{~m}$ long coastal section in the study area (Fig. 2). Note that the results characterise the transport rate in idealised conditions, in the absence of any obstacles and with no limitation for the amount of mobile sand. In real conditions the sand sheet is not continuous. The transport is modified by a large number of different obstacles and forms a small fraction, often as low as about $1 \%$, of the theoretical rates.

The annual average net alongshore transport (Fig. 3) and bulk transport (not shown) are, not unexpectedly, considerably (generally about 5 times) lower than similar values for the open Baltic Sea coasts [12]. Owing to the complicated geometry of Tallinn Bay both net and bulk transport rates vary largely along the

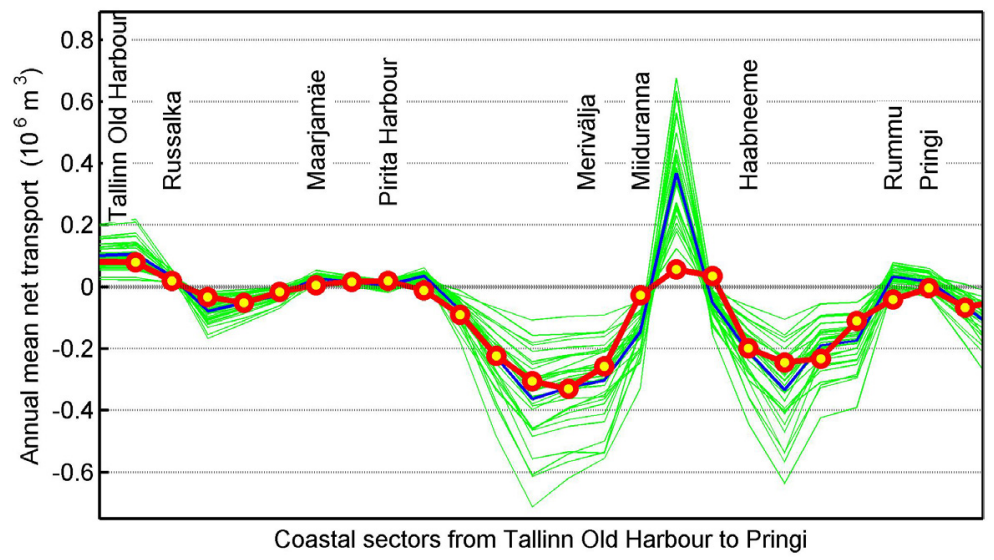

Figure 3: Wave-driven net alongshore sediment transport in the southern and eastern parts of Tallinn Bay. Green: transport in single years; blue: transport averaged over the years 1981-2012; red: transport averaged over three neighbouring nearshore grid points. Rapid variations in the transport rate near Miiduranna reflect the presence of a small bay to the north of Miiduranna Harbour. 
coast. The intensity of transport in the study area, near the Russalka monument, is relatively low even compared to typical transport rates in other coastal segments of Tallinn Bay [17].

Based on the qualitative description of wind and wave patterns in the Tallinn Bay area, it has been shown in previous research that the coastal segment from Tallinn Old Harbour to Pirita (Olympic) Harbour forms a single sediment compartment [17]. Interestingly, our simulations indicate the presence of a stable zero-crossing point of net alongshore sediment transport in the vicinity of the Russalka monument (Fig. 3). This zero-crossing is present in all single years of the 32-year simulation interval. Consequently, the location of the planned shift of the waterfront is a stable convergence area of sediment flux. As alongshore changes in the orientation of the coastline are fairly minor in this segment, even minor shifts in the location of the waterline may substantially affect the stability of this convergence area and lead to rapid relocation of large sand volumes.

\section{Intensity of accretion in the study area}

The convergence area described above is located in the bayhead and is mostly sheltered from intense waves. The relatively low but intermittent hydrodynamic activity, combined with limited supply of sand in the entire area, suggests that the accumulation area and an associated small beach belong to the family of "almost equilibrium" beaches that are common on the southern coast of the Gulf of Finland [18]. Such beaches evolve in a step-like manner: slow evolution is interspersed with rare but rapid events. As spatial resolution of standard profiling of beaches is often not sufficient to resolve their slow changes, we employ a combination of terrestrial (TLS) and airborne (ALS) laser scanning techniques [19] and an application of the inverse Bruun Rule [18] to characterise and quantify the changes during the slow evolution of the accumulation area.

The data set used in this study consists of both ALS and TLS data that are described in more detail in [19]. The ALS data were gathered using a Leica ALS50-II airborne laser scanner and pre-processed (the ground filtering and classification of the measured points) by the Estonian Land Board. Only the points classified as "ground" were used. The TLS survey was conducted with a commercial scanning device Leica ScanStation C10 with an average spatial resolution of $\sim 2500$ points $/ \mathrm{m}^{2}$ (one point for approximately $2 \times 2 \mathrm{~cm}$ ). Systematic elevation differences between the ALS and TLS data sets recorded at different time instants were eliminated using a constant-height area (a parking lot) near the beach as a horizontal reference.

The changes in the sand volume over the subaerial beach were obtained directly from the ALS and TLS data measured in 2008-2010 [20]. The accumulation rate was, as expected, highly variable. During the relatively calm years 2008-2010 the beach gained about $3500 \mathrm{~m}^{3}$ of sand each year, while during the four subsequent (somewhat more stormy) years it lost about $700 \mathrm{~m}^{3}$ of sand each year. During the entire time interval in question the beach gained about $4000 \mathrm{~m}^{3}$ of sand. The overall pattern of changes signals that sand is 
moving to the west. During the six years in question an almost $1 \mathrm{~m}$ thick sheet of sand has accumulated in the westernmost part of the sandy section.

The entire sandy beach is relatively young because the existing configuration of the shoreline between the Russalka area and Pirita Harbour was created in the mid-1970s. The seabed to the east of the beach is covered with pebbles, cobbles and boulders and contains only very limited amounts of sand. The pattern of alongshore transport (Fig. 3) suggests that (i) sand is transported to the beach only from a short nearshore section and (ii) the direction of alongshore sediment flux changes at a distance of about $2 \mathrm{~km}$ to the east of the beach. This pattern, together with the limited availability of sand in the entire sedimentary compartment, indicates that the western part of the beach, albeit rapidly filling, apparently is not yet in an equilibrium state.

The changes in the nearshore sand volume were evaluated using the concept of the equilibrium beach profile and the inverse Bruun Rule. If the beach profile is approximately in an equilibrium shape, the sand volume changes over the entire profile (per unit length of the shoreline) from the waterline down to the closure depth are [18]:

$$
\Delta V_{\Sigma} \approx d * \Delta y
$$

where $\Delta y$ is the relocation of the waterline. A straightforward generalisation of Eq. (2) makes it possible to directly evaluate the sediment gain or loss in an entire segment, provided the closure depth $d^{*}$ and the relocation rate $\Delta y$ are known [18].

The instantaneous location of the waterline depends on a number of local and short-term features. A reasonable representation of its relocation can be obtained from the shift of isolines of the subaerial beach. The shifts of isolines at $0.3,0.4$ and $0.5 \mathrm{~m}$ above mean water level were highly correlated and deviated from each other usually less than $10-15 \%$.

The changes in the underwater part of the beach evaluated using Eq. (2) were much (about three times) larger than similar changes in the subaerial beach. The nearshore area gained about $20000 \mathrm{~m}^{3}$ sand during the relatively calm years 2008-2010 while it lost about $10000 \mathrm{~m}^{3}$ sand during the four subsequent years. In total, the entire beach apparently gained more than $12000 \mathrm{~m}^{3}$ sand during the years 2008-2014; that is, more than $2000 \mathrm{~m}^{3} / \mathrm{yr}$ on average [20].

\section{Impact of a shift of the waterline}

The presented analysis suggests that the study area, especially the western part of the beach near Russalka, is not in an equilibrium state. The predominant process is the filling of the area between the existing beach and Tallinn Old Harbour with sand, evidently extending down to the closure depth. The entire equilibrium profile is not necessarily filled at once. A rough estimate of the actual location of the seaward border of the already filled part of the equilibrium profile can be obtained from aerial photos (Fig. 4) as the border of the strip of turbid water. The gradual widening of this strip qualitatively supports the conjecture about gradual the filling of the equilibrium profile. 




Figure 4: Approximate location of the seaward end of the equilibrium beach profile in the study area in 2002-2015, extracted from aerophotos of the Estonian Land Board. The red line indicates an estimate of the average position of the presented lines.

Given the closure depth of at least $2.2 \mathrm{~m}$ (a conservative estimate of this parameter is $2.9 \mathrm{~m} \mathrm{[15])} \mathrm{and} \mathrm{the} \mathrm{typical} \mathrm{scale} \mathrm{factor} A=0.063$ of Dean's equilibrium profile $d=A y^{2 / 3}$ in this area [17], the expected width of the equilibrium beach profile is at least $200 \mathrm{~m}$ and may reach $300 \mathrm{~m}$. This width has already been achieved in the area to the east of Russalka. The typical water depth in the area currently subject to filling is about $2 \mathrm{~m}$. Therefore, the abovediscussed accumulation rate is capable of filling about $10 \mathrm{~m}$ of the entire profile per year along the shoreline. Consequently, the entire $400 \mathrm{~m}$ long section from the Russalka area to Tallinn Old Harbour would eventually be filled up to an almost equilibrium state within roughly 40 years.

In other words, this section today functions as a compensation basin that effectively stops the wave-driven sediment transport into the harbour entrance (where only minor dredging is needed today). The described pattern suggests that any shift of the waterfront and seawalls in the study area will decrease the effective volume of this natural compensation basin and, in turn, accelerate the process of sand transport towards the harbour entrance. The direct effect of a waterfront shift may, however, lead to qualitative changes in the future shape of the equilibrium profile and thus in the processes that adjust its appearance today. According to the current plan, the construction of the new junction and the associated shift of the promenade would be roughly equivalent to an increase in 
the underwater sediment volume of $15,000 \mathrm{~m}^{3}$ of material. This is, in turn, equivalent to the sediment volume that is currently accumulated in the area in question within about 7 years [20].

The consequences of the planned reclamation, however, can be easily mitigated using various approaches.

A straightforward option is to build the planned junction and its extension (seaside promenade) on pillars.

If this would be either too expensive or unreasonable for other reasons, it is possible to make use of the established structure of net alongshore transport. Namely, a certain amount of sand could be pumped from the Russalka area to a distance of about $2 \mathrm{~km}$ to the east, beyond the divergence point of net alongshore transport in Fig. 3. Although single storms may bring some of the sediment from the neighbourhood of Pirita Harbour back to the Russalka area, on average the transport pattern tends to keep the coastal sediment to the east of the divergence point in question.

This feature can also be used for preventing the entrance to Tallinn Old Harbour from silting and to limit the sand accumulation rate in the entire area around Russalka. As discussed above, this part of the coast is filled almost exclusively by sand eroded from the nearshore of the coastal segment between Russalka and the divergence point about $2 \mathrm{~km}$ to the east of the monument. If sand is pumped to the east of this divergence point, it has low chances to be transported back to the Russalka area.

\section{Concluding remarks}

In the study area a natural compensation basin prevents the modest level of alongshore sediment flux from entering a sensitive area (harbour entrance). The obvious consequences of the reclamation of some parts of such a compensation basin are the weakening of its capacity and (possibly with some delay) an acceleration of the net transport of sediment into an undesirable area. The above discussion suggests that the effective volume of the compensation basin may be reduced by about $20 \%$ by the planned activities. The lesson is that even seemingly small activities may have unexpectedly large potential for remote impacts.

The alongshore gradient of net sediment transport characterises to some extent the stability of the major structural features of transport patterns such as the location of the divergence and convergence points and the direction of transport. Figure 3 suggests that these features apparently are very sensitive to the changes in the orientation of the coastline between Tallinn Old Harbour and Pirita Harbour. It is therefore likely that even a relatively modest shift in the waterfront near Russalka may lead to considerable changes in the entire pattern of alongshore sediment transport. It is heuristically obvious that such changes are particularly problematic in locations that govern the entire structure of littoral flow. While the basic features of processes in the vicinity of stable points of divergence usually do not change when the waterfront is moved farther offshore, the situation may be much more sensitive at convergence areas of sediment 
transport. These areas are usually located in bayheads where even a modest reclamation activity and small variation in the orientation of the shoreline may change not only the direction but also the entire pattern of sediment transport.

\section{Acknowledgements}

The research was supported by targeted financing IUT33-3 of the Estonian Ministry of Education and Research, grant 9125 by the Estonian Science Foundation and through support of the ERDF to the Centre of Excellence in Non-linear Studies CENS.

\section{References}

[1] Charlier, R.H., Chaineux, M.C.P. \& Morcos, S., Panorama of the history of coastal protection. Journal of Coastal Research, 21(1), pp. 79-111, 2005.

[2] Stancheva, M., Rangel-Buitrago, N., Anfuso, G., Palazov, A., Stanchev, H. \& Correa I., Expanding level of coastal armouring: Case studies from different countries. Journal of Coastal Research, Special Issue 64, pp. 1815-1819, 2011.

[3] Chang, T.C. \& Huang, S., Reclaiming the city: Waterfront development in Singapore. Urban Studies, 48(10), pp. 2085-2100, 2011.

[4] Hoyle, B., Global and local change on the port-city waterfront. Geographical Review, 90(3), pp. 395-417, 2000.

[5] Bernatchez, P. \& Fraser, C., Evolution of coastal defence structures and consequences for beach width trends, Québec, Canada. Journal of Coastal Research, 28(6), pp. 1550-1566, 2012.

[6] El-Asmar, H.M., Short term coastal changes along Damietta-Port Said coast northeast of the Nile Delta, Egypt. Journal of Coastal Research, 18(3), pp. 433-441, 2002.

[7] Bulleri, F. \& Chapman, M.G., The introduction of coastal infrastructure as a driver of change in marine environments. Journal of Applied Ecology, 47(1), pp. 26-35, 2010.

[8] Parnell, K.E., Delpeche, N., Didenkulova, I., Dolphin, T., Erm, A., Kask, A., Kelpšaite, L., Kurennoy, D., Quak, E., Räämet, A., Soomere, T., Terentjeva, A., Torsvik, T. \& Zaitseva-Pärnaste, I. Far-field vessel wakes in Tallinn Bay. Estonian Journal of Engineering, 14(4), pp. 273-302, 2008.

[9] Soomere, T., Wind wave statistics in Tallinn Bay. Boreal Environment Research, 10(2), pp. 103-118, 2005.

[10] Tuomi, L., Kahma, K.K. \& Pettersson, H., Wave hindcast statistics in the seasonally ice-covered Baltic Sea. Boreal Environment Research, 16(6), pp. 451-472, 2011.

[11] Keevallik, S. \& Soomere, T. Towards quantifying variations in wind parameters across the Gulf of Finland. Estonian Journal of Earth Sciences, 59(4), pp. 288-297, 2010. 
[12] Soomere, T. \& Viška, M., Simulated sediment transport along the eastern coast of the Baltic Sea. Journal of Marine Systems, 129, pp. 96-105, 2014.

[13] Soomere, T., Pindsoo, K., Bishop, S.R., Käärd, A. \& Valdmann, A., Mapping wave set-up near a complex geometric urban coastline. Natural Hazards and Earth System Science, 13(11), pp. 3049-3061, 2013.

[14] Dean, R.G., Equilibrium beach profiles: Characteristics and applications. Journal of Coastal Research, 7(1), pp. 53-84, 1991.

[15] Soomere, T., Viška, M. \& Eelsalu, M. 2013. Spatial variations of wave loads and closure depth along the eastern Baltic Sea coast. Estonian Journal of Engineering, 19(2), pp. 93-109, 2013.

[16] Coastal Engineering Manual, Department of the Army. U.S. Army Corps of Engineers. Manual No. 1110-2-1100, 2002.

[17] Soomere, T., Kask, A., Kask, J. \& Nerman, R., Transport and distribution of bottom sediments at Pirita Beach. Estonian Journal of Earth Sciences, 56(4), pp. 233-254, 2007.

[18] Kask, A., Soomere, T., Healy, T.R. \& Delpeche, N., Sediment transport patterns and rapid estimates of net loss of sediments for "almost equilibrium" beaches. Journal of Coastal Research, Special Issue 56, pp. 971-975, 2009.

[19] Julge, K., Eelsalu, M., Grünthal, E., Talvik, S., Ellmann, A., Soomere, T. \& Tõnisson, H., Combining airborne and terrestrial laser scanning to monitor coastal processes. The 6th IEEE/OES Baltic Symposium Measuring and Modeling of Multi-Scale Interactions in the Marine Environment, May 26-29, Tallinn Estonia, IEEE Conference Publications, 10 pp., doi: 10.1109/BALTIC.2014.6887874, 2014.

[20] Soomere, T., Eelsalu, M. \& Pindsoo, K., Rannasete bilanss Miidurannast Tallinna Vanasadamani (The budget of coastal sediment from Miiduranna Harbour to Tallinn Old Harbour). Research report. Institute of Cybernetics at Tallinn University of Technology, 91 pp., 2014. 